\title{
Evaluating the protective effects of vitamin $C$ on serum and erythrocyte cholinesterase activity of male rats exposed to malathion
}

Faezeh Ghorbani Taherdehi ${ }^{1}$, Mohammad Reza Nikravesh², Mehdi Jalali², Alireza Fazel ${ }^{2}$

\author{
${ }^{1}$ M.Sc. Student of Anatomy, Department of Anatomy and Cell Biology, School of Medicine, Mashhad University of \\ Medical Sciences, Mashhad, Iran \\ ${ }^{2} \mathrm{Ph}$.D. of Anatomy, Professor, Department of Anatomy and Cell Biology, School of Medicine, Mashhad University \\ of Medical Sciences, Mashhad, Iran
}

\section{Type of article: Original}

\begin{abstract}
Introduction: Malathion is one of organophosphate poisons (OPPs) that inhibit cholinesterase activity and induce oxidative stress in target organs, such as the reproductive system. The aim of this study was to assess the effects of Malathion on serum and erythrocyte cholinesterase activity in male rats and also to assess the protective effects of vitamin $\mathrm{C}$ in this regard.

Methods: This experimental study was performed in the Pharmacology Laboratory of the Pharmacy Faculty and in the Advanced Histology Techniques Laboratory of the Medical Faculty of Mashhad University of Medical Sciences (MUMS) in January 2014. Thirty male wistar rats, weighting 200-250 g, were divided into five groups of six. The different groups were exposed as follows: group 1: Malathion $50 \mathrm{mg} / \mathrm{kg}$; group 2: Vitamin C; group 3: Malathion plus Vitamin $\mathrm{C}$ with the specified doses; sham group: normal saline; and control group: no exposure. After six weeks, $3 \mathrm{ml}$ blood samples were taken from the rats, and titrimetric and Ellman methods were used to assess serum and erythrocyte cholinesterase activity, respectively. The data was analyzed by SPSS 16, and $\mathrm{p}<0.05$ was considered significant.

Results: The activities of serum and erythrocyte cholinesterase were inhibited significantly in the Malathion exposed group compared to the control group $(\mathrm{p}<0.001)$. The administration of Vitamin $\mathrm{C}$ alone significantly increased the activities of serum and erythrocyte cholinesterase. The serum and erythrocyte cholinesterase inhibition showed improvement in the group that received both Malathion and Vitamin C.

Conclusion: Malathion reduced the activities of serum and erythrocyte cholinesterase in exposed animals. It probably has the same intoxication effects on people who are exposed. Improvement of cholinesterase activity by antioxidant effects of Vitamin C suggests that Vitamin C supplementation can be used to decrease side effects of OPP exposure.
\end{abstract}

Keywords: Acetylcholinesterase, Malathion, Rat, Vitamin C

\section{Introduction}

The organophosphate poisons (OPPs), i.e., herbicides and pesticides, are chemical compounds that are hazardous to environment (1). The indiscriminate use of OPPs is one of the main concerns of WHO. Increased population followed by increased demands for food, especially agricultural products, has pushed farmers to increase their products, and this has led to the greater use of pesticides and poisons (2). OPPs can enter the human body through skin and mucous membranes, such as eyes, mouth, or by inhaling the poison while it is being sprayed. Generally, OPPs have high toxicity and induce many negative effects on different organs (3). They can cause many complications, including nausea, dizziness, dyspnea, and urticaria (4). The human organs and systems that can be affected by OPPs are the liver, kidneys, pancreas, heart, immune system, and vascular walls (5-7). Studies have

\section{Corresponding author:}

Professor Dr. Mohammad Reza Nikravesh, Department of Anatomy and Cell Biology, School of Medicine, Mashhad University of Medical Sciences, Azadi Sq., Mashhad, Iran.

Tel: +98.5138002490, Fax: +98.9153114419, Email: Nikraveshmr@mums.ac.ir

Received: February 20, 2016, Accepted: May 01, 2016, Published: July 2016

iThenticate screening: February 22, 2016, English editing: May 17, 2016, Quality control: June 26, 2016

(C) 2016 The Authors. This is an open access article under the terms of the Creative Commons Attribution-NonCommercialNoDerivs License, which permits use and distribution in any medium, provided the original work is properly cited, the use is non-commercial and no modifications or adaptations are made. 
shown the destructive effects of OPPs on the endocrine and reproductive systems of animals (8). One of the effects of these pesticides is that they produce free radicals, which consequently change cell antioxidant systems and induce membrane lipid peroxidation (9). In the human body, there are two types of cholinesterase enzyme; one is the real cholinesterase (acetyl-cholinesterase), which is in the red blood cells, neural systems, and muscular systems. The other type is pseudo-cholinesterase, which has a structure similar to that of acetyl-cholinesterase and is in serum, the pancreas, the liver, the brain, and in heart cells (10-12). OPPs inhibit the activity of both types of cholinesterase, causing the accumulation of acetylcholine neurotransmitter in the sympathetic and parasympathetic fibers and in muscles' neural connections. As a consequence, this accumulation disrupts the transportation of messages through the cholinergic synapses $(4,13)$. Decreased serum cholinesterase activity (PchE) is a sign of acute intoxication, and decreased acetylcholinesterase (AchE) in erythrocytes indicates chronic intoxication (14). Malathion is one of the most important and most used OPPs in world, including Iran. Malathion (diethyl methoxy thio phosphine thio succinate) is a parasympatholytic organophosphadate poison, which makes an irreversible bond/link with cholinesterase (15). After being absorbed into the body, Malathion is converted to malaoxon and oxygen analogs by the metabolism, and malaoxon is 61 times more toxic than Malathion (16). The mechanism of induced oxidative stress by Malathion is producing free radicals including reactive oxygen species (ROSs). ROSs change antioxidants' systemic defense in different organs (17). Oxidative stress harms many macromolecules by starting destructive processes, including lipid peroxidation, DNA oxidation, protein oxidation, inactivation of enzymes, and causing dysfunction in different membranes (18). Most of insecticides have hydrophobic molecules that readily attach to biological membranes, especially to the two phospholipid layers of membranes, which causes membrane lipid peroxidation (13). One of the ways of dealing with OPP intoxication is by using antioxidants, which prevent excessive production of toxic free radicals and the damage they induce. Vitamin $\mathrm{C}$ or ascorbic acid is a known antioxidant that seems necessary in many processes in the body, including forming bones and and repairing tissue scars (19). Vitamin C decreases oxidative stress and lipid peroxidation, thereby preventing many damaging processes in cells (20). Since Malathion is one of the most commonly used OPPs and it inhibits cholinesterase activity, our aim in this study was to determine the toxic effects of Malathion on serum and erythrocyte cholinesterase activity in male rats. Another aim was to assess the protective effects of Vitamin C in this regard.

\section{Material and Methods}

\subsection{Research design and Sample size}

This was an experimental study performed in pharmacology laboratory of Pharmacy Faculty and in advanced histology techniques laboratory of Medical Faculty of Mashhad University of Medical Sciences (MUMS) in January 2014. The study protocol was approved by Ethic Committee of Mashhad University of Medical Science. The study's sample size was calculated based on a formula and previous studies $(11,13)$. The study population consisted of 30 two-month-old Vistar rats that weighed between 200 and 250 grams.

\subsection{Experiment and data collection}

The rats were assigned randomly assigned into five groups of six members each. The groups' exposures were as follows:

1) Experimental group 1: daily administration of $50 \mathrm{mg} / \mathrm{kg}$ of Malathion in normal saline solution

2) Experimental group 2: daily administration of $200 \mathrm{mg} / \mathrm{kg}$ of vitamin $\mathrm{C}$

3) Experimental group 3: daily administration of $50 \mathrm{mg} / \mathrm{kg}$ of Malathion and $200 \mathrm{mg} / \mathrm{kg}$ of vitamin C

4) Sham group: administration of $50 \mathrm{mg} / \mathrm{kg}$ of normal saline

5) Control group: received nothing $(21,22)$.

Exposure to Malathion, Vitamin C, and normal saline (product of Sigma Company) were by intra-peritoneal injection (23). After six weeks of daily exposure, the levels of acetylcholinesterase in erythrocyte and serum were measured. Malathion 99\% was purchased from Ariashimi Company and stock solution with a concentration of 50 $\mathrm{mg} / \mathrm{ml}$ in normal saline was prepared as needed. To measure erythrocyte cholinesterase, the rats were anesthetized with intra-peritoneal injection of $0.1 \mathrm{ml} / 100 \mathrm{~g}$ (24). A 3-ml blood sample was taken from animal heart with heparinized syringes. Half of the blood sample was centrifuged and then $3 \mathrm{ml}$ of reactant DTNB (dithiobis nitrobenzoic acid) and $100 \mathrm{ml}$ of the substrate solution (acetyl thio colin idone) were added to a glass tube, and the tube was placed in a water bath at $37^{\circ} \mathrm{C}$ for 10 seconds. Then, $100 \mu \mathrm{l}$ of the hemolysis solution were added, and the glass tube remained in the water bath at $37^{\circ} \mathrm{C}$ for 10 more minutes, after which $1 \mathrm{ml}$ of reactant stopper was added to it. The contents of the tube were stirred, and the tube was removed from the water bath. The blank samples were prepared with this same method with the exception that, in the last step after adding reactant stopper, $100 \mu 1$ of hemolysis solution were added to each tube that was taken out of the water bath. Since each hemolyzed sample had 
its own absorption characteristics, one separate blank was prepared independently for use in determining the enzyme activity in each sample, and each sample's absorption in front in of its blank was read immediately at the wavelength of $440 \mathrm{~nm}$. This process was repeated three times for each hemolyzed sample, and their mean was calculated. The element method was used to measure the inhibition of acetyl-cholinesterase enzyme in erythrocyte (51), and serum cholinesterase was measured with titrometery. In this method, the main solution was acetylcholine chloride, and $0.5 \mathrm{ml}$ of serum was added to $10 \mathrm{ml}$ of the acetylcholine chloride. Then, two drops of Trizol reagent (a $\mathrm{pH}$ indicator that is yellow in acidic condition and purple in alkaline condition) were added and mixed. Also, $5 \mathrm{~cm} 3$ of $10 \%$ acetic acid were added to the acetylcholine chloride to enhance its stability.

\subsection{Statistical analysis}

The collected results were entered into and analyzed by SPSS version 16 (SPSS Inc., Chicago, Illinois, USA). The statistical analysis of erythrocyte cholinesterase was made by ANOVA, and the means were compared by the Tukey-Kramer test. Since serum cholinesterase data were reported as percentages, the Mann-Whiney test was used to compare the means between the groups, and $p$-values $<0.05$ were considered to be significant.

\section{Results}

The mean of serum cholinesterase activity was $26.66 \pm 2.88,24 \pm 4.18$, and $29.16 \pm 4.91$ in the control, normal saline, and Vitamin C groups. These means in the Malathion and Malathion + Vitamin C groups were $12 \pm 2.73$ and $18 \pm 4.47$, respectively. The results indicated that the activity of serum cholinesterase in the Malathion group was significantly decreased compared to the other groups. The differences between the means for the control group, normal saline group, and Vitamin C groups and the mean of the Malathion group were significant ( $\mathrm{p}$-value $<0.001$ for all three comparisons) (Table 1). The mean of erythrocyte cholinesterase activities in the control, normal saline, and Vitamin $\mathrm{C}$ groups were $3.33 \pm 0.28,2.72 \pm 0.42$, and $2.8 \pm 0.43$. These means in the Malathion and the Malathion + Vitamin C groups were $1.29 \pm 0.17$ and $2.04 \pm 0.18$, respectively. The comparison of mean erythrocyte cholinesterase activities in the control, normal saline, Vitamin $\mathrm{C}$ and Malathion + Vitamin $\mathrm{C}$ groups with the Malathion group showed significant differences $(p<0.0001$ for the first three groups and $p=0.002$ for the last group) (Table 2). Regarding the protective effects of Vitamin C, the comparison of mean and standard deviation of both serum and erythrocyte cholinesterase activity between the control group and the group that received only Vitamin $C$ showed that enzyme activity was significantly improved by the administration of Vitamin $C(p=0.03$ for both comparisons). Our results also showed that the mean of serum cholinesterase activity in the rats that received Malathion + Vitamin $C$ was not significantly different from the control group $(\mathrm{p}=0.009)$, while the difference between the group that was exposed only to Malathion and the control group was significant $(\mathrm{p}<0.0001)$. The differences between the mean of erythrocyte cholinesterase activity in the control group and the Malathion and the Malathion + Vitamin $C$ groups also were significant $(\mathrm{p}<0.0001$ for both).

Table 1. Comparison of serum cholinesterase activity between experimental groups and with the control group

\begin{tabular}{|l|l|l|l|}
\hline Groups & $\begin{array}{l}\text { Serum cholinesterase; } \\
\text { Mean } \pm \text { SD }\end{array}$ & $\begin{array}{l}\text { p-value (Comparison of } \\
\text { groups with control) }\end{array}$ & $\begin{array}{l}\text { p-value (Comparison of } \\
\text { groups with Malathion) }\end{array}$ \\
\hline Control & $26.66 \pm 2.88$ & - & $<0.0001$ \\
\hline Normal saline $50 \mathrm{ml} / \mathrm{kg}$ & $24 \pm 4.18$ & 0.38 & $<0.0001$ \\
\hline Malathion $50 \mathrm{mg} / \mathrm{kg}$ & $12 \pm 2.73$ & $<0.0001$ & - \\
\hline Vitamin C $200 \mathrm{mg} / \mathrm{kg}$ & $29.16 \pm 4.91$ & 0.03 & $<0.0001$ \\
\hline $\begin{array}{l}\text { Malathion } 50 \mathrm{mg} / \mathrm{kg}+ \\
\text { Vitamin C } 200 \mathrm{mg} / \mathrm{kg}\end{array}$ & 18.4 .47 & 0.009 & \\
\hline
\end{tabular}

Table 2. Comparison of erythrocyte cholinesterase activity between experimental groups and with the control group

\begin{tabular}{|l|l|l|l|}
\hline Groups & $\begin{array}{l}\text { Erythrocytecholinesterase; } \\
\text { Mean } \pm \text { SD }\end{array}$ & $\begin{array}{l}\text {-value (Comparison of } \\
\text { groups with control) }\end{array}$ & $\begin{array}{l}\text { p-value (Comparison of } \\
\text { groups with Sham) }\end{array}$ \\
\hline Control & $3.33 \pm 0.28$ & - & $<0.0001$ \\
\hline Normal saline $50 \mathrm{ml} / \mathrm{kg}$ & $2.72 \pm 0.42$ & 0.02 & $<0.0001$ \\
\hline Malathion $50 \mathrm{mg} / \mathrm{kg}$ & $1.29 \pm 0.17$ & $<0.0001$ & - \\
\hline Vitamin C $200 \mathrm{mg} / \mathrm{kg}$ & $2.8 \pm 0.43$ & 0.03 & $<0.0001$ \\
\hline $\begin{array}{l}\text { Malathion } 50 \mathrm{mg} / \mathrm{kg}+ \\
\text { Vitamin C } 200 \mathrm{mg} / \mathrm{kg}\end{array}$ & $2.04 \pm 0.18$ & $<0.0001$ & 0.002 \\
\hline
\end{tabular}




\section{Discussion}

This study aimed to evaluate the activity level of serum and erythrocyte cholinesterase in male rats exposed to Malathion and Vitamin C. Our results showed that the activity of both serum and erythrocyte cholinesterase significantly decreased in rats exposed to Malathion compared with control group $(\mathrm{p}<0.0001)$. The administration of Vitamin $\mathrm{C}$ alone significantly increased serum and erythrocyte cholinesterase activity in comparison with control group $(\mathrm{p}<0.03)$. The difference between serum cholinesterase activity in the rats that received Malathion + Vitamin $\mathrm{C}$ and the control group was not significant $(\mathrm{p}=0.09)$, however the difference between mean of erythrocyte cholinesterase activity was significant $(\mathrm{p}<0.0001)$. These findings indicated that Vitamin $\mathrm{C}$ had a protective effect on serum cholinesterase activity but not on erythrocyte cholinesterase activity. The results of this study showed that serum and erythrocyte cholinesterase activities in the group exposed to Malathion were significantly less than the control group ( $\mathrm{p}<0.001)$, which were similar to the results of other studies. These findings confirmed the results of Inbaraj et al.'s study that was performed on fish exposed to Malathion (25). They showed that Malathion demonstrated a dose-dependent inhibition of brain acetylcholinesterase activity. The results of Ansari et al.'s study on fish and Abdollahi et al.'s study on rats also demonstrated the decrease in acetylcholinesterase activity upon exposure to OPPs, especially Malathion $(26,27)$. Another study that evaluated the effects of three OPPs (Malathion, Diazinon, and Parathion) on wildfowl eggs showed that all of these OPPs can significantly decrease the activity of fetal plasma cholinesterase (28). The results of all of these studies indicated the intoxication of live animals by OPPs, especially Malathion. Since OPPs are very commonly used poisons worldwide, intoxication by them seems inevitable, therefore attention is now being focused on determining ways to reduce their intoxication. Antioxidants, including Vitamin C, are one of the suggested products. The studies' results have shown that Vitamin C can reduce the production of free radicals produced by oxidative stress (13). In our study, one group of rats received Vitamin C and Malathion, and the results illustrated a significant increase in serum cholinesterase compared with the group that received only Malathion. This finding was similar to the results of Uzun et al.'s study about Malathion-induced testicular toxicity in male rats and the protective effect of vtamins $C$ and E (13). Their results indicated that cotreatment of rats exposed to Malathion with Vitamins $\mathrm{E}$ and $\mathrm{C}$ had a protective effect on sperm count, sperm motility, and abnormal sperm numbers. Kalender et al. also found that Vitamins $\mathrm{C}$ and $\mathrm{E}$ can reduce Malathion hepatotoxicity (29). The reduction in serum cholinesterase caused by Malathion restrains the activity of hypothalamus-hypophysis-gonadal axis and leads to the reduction of the production of sexual hormones and causes disorders in the reproductive system (30). It must be considered that the results of this study only showed changes of serum and erythrocyte cholinesterase activity under Malathion exposure and also indicated that Vitamin C, as an antioxidant, reduced the effects of oxidative stress caused by Malathion intoxication. However, the results do not imply any protective effect of Vitamin $\mathrm{C}$ for the reproductive system upon exposure to Malathion. Since antioxidants can reduce the harmful effects of exposure to OPPs, people who are exposed to OPPs in direct ways (contact or inhalation) or indirect ways (using contaminated agricultural products or proteins), the use of antioxidants, such as Vitamin C, may decrease the damage.

\section{Conclusions}

Our findings showed that Malathion decreased the activity of serum and erythrocyte cholinesterase in exposed rats and that the administration of Vitamin $\mathrm{C}$ reduced the induced damage. Since Malathion is a very commonly used insecticide and people are exposed to it in different ways, it could have similar intoxication effects on people who are exposed to it. Vitamin $\mathrm{C}$ has been shown to have protective effects against Malathion toxicity in animal studies, therefore Vitamin C supplementation is suggested for people who are exposed to Malathion. However, to generalize these results, additional studies with larger sample sizes or different populations are recommended.

\section{Acknowledgments:}

This article was a part of Master's thesis in Anatomy, which was conducted by research funding number 922840 in Mashhad University of Medical Sciences. The authors thank the Research Chancellor of MUMS for funding the project. We also appreciated the technical assistance provided by Ms. Motejaded, who works in the Histology Laboratory of the Medical Faculty. We also appreciated the assistance provided by the Toxicology Department of the Pharmacy Faculty.

\section{Conflict of Interest:}

There is no conflict of interest to be declared.

\section{Authors' contributions:}

All authors contributed to this project and article equally. All authors read and approved the final manuscript. 


\section{References:}

1) Bonilla E, Hernandez F, Cortés L, Mendoza M, Mejia J, Carrillo E, et al. Effects of the insecticides malathion and diazinon on the early oogenesis in mice in vitro. Environ Toxicol. 2008; 23(2): 240-5. doi:10.1002/tox.20332. PMID: 18214912.

2) Najafi GR, Salami S, Karimi A. The effect of diazinon on testicular tissue in adult male rat: a histopathological study. Urmia Medical Journal. 2010; 20(4): 313-9.

3) Sheffield SR, Lochmiller RL. Effects of field exposure to diazinon on small mammals inhabiting a semienclosed prairie grassland ecosystem. I. Ecological and reproductive effects. Environ Toxicol Chem. 2001; 20(2): 284-96. doi: 10.1002/etc.5620200209. PMID: 11351428.

4) Sarabia L, Maurer I, Bustos-Obregon E. Melatonin prevents damage elicited by the organophosphorous pesticide diazinon on mouse sperm DNA. Ecotoxicol Environ Saf. 2009; 72(2): 663-8. doi: 10.1016/j.ecoenv.2008.04.023. PMID: 18571725.

5) Uner N, Oruç EO, Sevgiler Y, Şahin N, Durmaz H, Usta D. Effects of diazinon on acetylcholinesterase activity and lipid peroxidation in the brain of Oreochromis niloticus. Environ Toxicol Pharmacol. 2006; 21(3): 241-5. doi: 10.1016/j.etap.2005.08.007. PMID: 21783664.

6) Sargazi Z, Nikravesh MR, Jalali M, Sadeghnia HR, Rahimi Anbarkeh F, Mohammadzadeh L. DiazinonInduced Ovarian Toxicity and Protection by Vitamins E. Iranian Journal of Toxicology. 2014; 8(26): 1130 5 .

7) Sargazi Z, Nikravesh MR, Jalali M, Sadeghnia HR, Rahimi anbarkeh F, Mohammadzadeh L. GenderRelated Differences in Sensitivity to Diazinon in Gonads of Adult Rats and the Protective Effect of Vitamin E. International journal of women's health and reproduction sciences. 2015; 3(1): 40-7.

8) McLachlan JA. Environmental signaling: what embryos and evolution teach us about endocrine disrupting chemicals. Endocr Rev. 2001; 22(3): 319-41. doi: 10.1210/edrv.22.3.0432. PMID: 11399747.

9) Khan SM, Sobti RC, Kataria L. Pesticide-induced alteration in mice hepato-oxidative status and protective effects of black tea extract. Clin Chim Acta. 2005; 358(1-2): 131-8. doi: 10.1016/j.cccn.2005.02.015. PMID: 15885683.

10) Mehrani H. Protective effect of polyurethane immobilized human butyrylcholinesterase against parathion inhalation in rat. Environ Toxicol Pharmacol. 2004; 16(3): 179-85. doi: 10.1016/j.etap.2004.01.001. PMID: 21782705 .

11) Rahimi Anbarkeh F, Nikravesh MR, Jalali Mehdi, Sadeghnia HR, Sargazi Z. The Effect of Diazinon on Cholinesterase Activity in Plasma and Erythrocytes of Male and Female Rats and the Protective Role of Vitamin E. Sci J Hamadan Univ Med Sci. 2015; 21(4): 294-303.

12) Rahimi Anbarkeh F, Nikravesh MR, Jalali M, Sadeghnia HR, Sargazi Z. Assessment of erythrocyte and serum cholinesterase activity in male rats treated with diazinon, and protective role of vitamin e. Journal of sabzevar university of medical sciences. 2014; 21(4): 550-8.

13) Uzun FG, Kalender S, Durak D, Demir F, Kalender Y. Malathion-induced testicular toxicity in male rats and the protective effect of vitamins C and E. Food Chem Toxicol. 2009; 47(8): 1903-8. doi: 10.1016/j.fct.2009.05.001. PMID: 19442699.

14) Barkhordari ART HH, Mosaddegh MD, Fallahzadeh H. Assessment of Ache in worker exposed to OP pesticides. J Community Med . 2012; 4(1-2): 9-16.

15) Bonner MR, Coble J, Blair A, Beane Freeman LE, Hoppin JA, Sandler DP, et al. Malathion exposure and the incidence of cancer in the agricultural health study. Am J Epidemiol. 2007; 166(9): 1023-34. doi: 10.1093/aje/kwm182. PMID: 17720683.

16) Edwards D. Reregistration eligibility decision for malathion. US Environmental Protection AgencyPrevention, Pesticides and Toxic Substances EPA. 2006; 9: 738.

17) Perry MJ, Venners SA, Chen X, Liu X, Tang G, Xing H, et al. Organophosphorous pesticide exposures and sperm quality. Reprod Toxicol. 2011; 31(1): 75-9. doi: 10.1016/j.reprotox.2010.08.006. PMID: 20850521, PMCID: PMC3035720.

18) Esteghamati AR, Zarban A, Doosti M. Evaulation of antioxidant status and oxidative stress markers in type II diabetes mellitus. Iranian Journal of Endocrinology and Metabolism. 2001; 3(4): 239-45.

19) Handelman GJ. Vitamin C deficiency in dialysis patients-are we perceiving the tip of an iceberg? Nephrol Dial Transplant. 2007; 22(2): 328-31. doi: 10.1093/ndt/gfl534. PMID: 17107966.

20) Johnson VJ, Rosenberg AM, Lee K, Blakley BR. Increased T-lymphocyte dependent antibody production in female SJL/J mice following exposure to commercial grade malathion. Toxicology. 2002; 170(1-2): 11929. doi: 10.1016/S0300-483X(01)00515-7. PMID: 11750089. 
21) Fortunato JJ, Agostinho FR, RÉus GZ, Petronilho FC, Dal-Pizzol F, Quevedo J. Lipid peroxidative damage on malathion exposure in rats. Neurotox Res. 2006; 9(1): 23-8. doi: 10.1007/BF03033304. PMID: 16464749.

22) Choudhary N, Goyal R, Joshi S. Effect of malathion on reproductive system of male rats. J Environ Biol. 2008; 29(2): 259-6. PMID: 18831386.

23) Uzunhisarcikli M, Kalender Y, Dirican K, Kalender S, Ogutcu A, Buyukkomurcu F. Acute, subacute and subchronic administration of methyl parathion-induced testicular damage in male rats and protective role of vitamins $\mathrm{C}$ and E. Pesticide biochemistry and physiology. 2007; 87(2): 115-22. doi: 10.1016/j.pestbp.2006.06.010.

24) Shokrzade Lamoki M, Pakravan N, Sheikholeslamian S. The protective effect of N-acetyl cysteine on glutathione levels and serum cholinesterase in acute poisoning of diazinon, in mice. J Mazandaran Univ Med Sci. 2013; 22(2-3): 2-11.

25) Inbaraj RM, Haider S. Effect of malathion and endosulfan on brain acetylcholinesterase and ovarian steroidogenesis of Channa punctatus (bloch). Ecotoxicol Environ Saf. 1988; 16(2): 123-8. doi: 10.1016/0147-6513(88)90025-5. PMID: 3234285.

26) Abdollahi M, Ebrahimzadeh MBM. In vitro inhibition of acetylcholinesterase activity in human red blood cells by cadmium and lead. Acta Medica Iranica. 1998; 36(2): 74-8.

27) Ansari BA, Kumar K. Malathion toxicity: in vivo inhibition of acetylcholinesterase in the fish Brachydanio rerio (Cyprinidae). Toxicol Lett. 1984; 20(3): 283-7. doi: 10.1016/0378-4274(84)90161-9. PMID: 6701915.

28) Yu Y, Yang A, Zhang J, Hu S. Maternal exposure to the mixture of organophosphorus pesticides induces reproductive dysfunction in the offspring. Environ Toxicol. 2013; 28(9): 507-15. PMID: 21793158.

29) Kalender S, Uzun FG, Durak D, Demir F, Kalender Y. Malathion-induced hepatotoxicity in rats: the effects of vitamins C and E. Food Chem Toxicol. 2010; 48(2): 633-8. doi: 10.1016/j.fct.2009.11.044. PMID: 19941925.

30) Coye MJ, Lowe JA, Maddy KT. Biological monitoring of agricultural workers exposed to pesticides: I. Cholinesterase activity determinations. J Occup Med. 1986; 28(8): 619-27. doi: 10.1097/00043764198608000-00018. PMID: 3746482. 